\title{
SUP\&R DSS: A sustainability-based decision support system for road
} pavements

João Santos $^{\text {a, * }}$, Sara Bressi ${ }^{\text {b }}$, Veronique Cerezo ${ }^{c}$, Davide Lo Presti ${ }^{d}$

a Department of Construction Management \& Engineering, Faculty of Engineering Technology, University of Twente, Enschede, the Netherlands

${ }^{\mathrm{b}}$ Department of Civil, Environmental, Aerospace, Materials Engineering (DICAM), Viale delle Scienze Edificio 8. University of Palermo, Italy

' LUNAM Universite, IFSTTAR, AME-EASE, Route de Bouaye, CS4, F-44341 Bouguenais, France

${ }^{\mathrm{d}}$ Nottingham Transportation Engineering Centre, University of Nottingham Faculty of Engineering, The University of Nottingham, University Park,

Nottingham, NG7 2RD, UK

2 To cite this article: oão Santos, Sara Bressi, Veronique Cerezo, Davide Lo Presti, SUP\&R DSS: A 3 sustainability-based decision support system for road pavements, Journal of Cleaner Production,

4 Volume 206, 2019, Pages 524-540, ISSN 0959-6526,

5 To link to this article: https://doi.org/10.1016/j.jclepro.2018.08.308.

6 (http://www.sciencedirect.com/science/article/pii/S0959652618326696)

7

8 Original version of the manuscript:

9 https://www.sciencedirect.com/science/article/pii/S0959652618326696

10

11 
1 SUP\&R DSS: A sustainability-based decision support system for road 2 pavements

3 João Santos, PhD

4 IFSTTAR, AME-EASE, Route de Bouaye, CS4, F-44341 Bouguenais, France, Email:

5 j.m.oliveiradossantos@utwente.nl

6

7 Sara Bressi, PhD

8 Department of Civil, Environmental, Aerospace, Materials Engineering (DICAM), Viale delle 9 Scienze Edificio 8. University of Palermo, Italy.

10

11 Veronique Cerezo, PhD

12 LUNAM Université, IFSTTAR, AME-EASE, Route de Bouaye, CS4, F-44341 Bouguenais, 13 France.

14

\section{Davide Lo Presti, PhD}

16 Nottingham Transportation Engineering Centre, University of Nottingham Faculty of 17 Engineering, The University of Nottingham, University Park, Nottingham, NG7 2RD.

18 davide.lopresti@nottingham.ac.uk / davide.lopresti@unipa.it 


\section{Sustainability-based decision support system for road pavement surfaces}

3 Abstract

4 As pavement community members head into the future, the increasing social pressure towards 5 the incorporation of sustainable principles into their work urge them (1) to come up with new 6 materials and practices that reduce the negative impacts of their activities in the surroundings 7 and (2) to develop methodologies and tools to encourage sustainable decision-making. To this 8 end, this paper presents the development of a life cycle, performance-based, sustainability 9 decision support system (DSS) for helping decision-makers (DMs)/stakeholders to prioritize 10 alternative technologies for transportation systems with the ultimate objective of fostering 11 sustainability in transportation projects.

The framework relies on a multi-criteria decision analysis (MCDA) method to rank the sustainability of alternatives based on their life cycle sustainability performances and the relative priorities with respect to each environmental, economic and social criterion. The applicability of the proposed DSS is illustrated by means of a case study that aims to identify the most sustainable asphalt mixture amongst several promising options ranging from low to hot temperature asphalt for wearing courses of flexible road pavements. The sustainability assessment applies life cycle-based approaches to quantify the values of a set of indicators purposely and methodologically selected to capture the cause-effect link between the general concepts of the three Wellbeing dimensions of sustainability, i.e., environmental, economic and social, and the infrastructure construction and maintenance practice. The results show that a foamed WMA mixture with a RAP content of $50 \%$ is the most sustainable among the competing alternatives. Furthermore, a sensitivity analysis conducted to investigate the influence of indicators weights and parameters of the MCDA method on the stability of the ranking showed that its first position in the ranking remained unaffected.

Keywords: Low temperature asphalt mixtures; sustainable pavement construction and management; life cycle assessment; life cycle costs analysis; multi-criteria decision making. 


\section{Introduction}

More than ever before, sustainable development is a key topic for all development activities. It can be understood as the integration of environmental, economic and social dimensions in such a way that the goods produced and the services provided do not compromise the integrity of environmental systems, while minimizing their vulnerability and balance their natural recharge (World Road Association, 2016).

In view of that, the challenge lays on how to incorporate the sustainability concept in different development sectors in order to achieve their goals. The urgency of succeeding in the accomplishment of this challenge is particularly meaningful for the transportation sector in general, and for the road transportation mode in particular. For instance, in Organisation for Economic Co-operation and Development (OECD) countries, $\mathrm{CO}_{2}$ emissions from the transport sector totalled 9000 billion tonnes in 2015, representing about $18 \%$ of all man-made emissions (ITF, 2017). Yet according to ITF (2017), the emissions from road transport, both freight and passenger, are expected to increase by more than $70 \%$ between 2015 and 2050 . It is not clear yet what is the specific contribution that the infrastructures have in these numbers. Surely, road pavements are a fundamental asset of the road transport system and undertaking more sustainable decisions would have a great impact. In fact, they are large in project scope and involve considerable amounts of financial resources (ERF, 2013). Furthermore, their construction involves the depletion of non-renewable resources, significant energy consumption, emissions and waste generation associated with the production of pavement materials, which not only impact negatively the environment, but also cause social perturbations (Santero and Horvath, 2009). This is further worsened by the project's long construction time and service life that, ideally, requires maintenance to be performed on a regular basis. Based on this picture, it is evident that organizations within the pavement industry cannot go on with business as in the past and need to put in practice sustainable development principles in an effort to lower and/or mitigate its negative environmental, social, and economic impacts while constructing and preserving these assets.

\subsection{Sustainable asphalt technologies}

This awareness has led to meaningful research efforts to improve the conventional construction and maintenance practices by developing and implementing more sustainable technologies. One example of those endeavours is the SUP\&R ITN (Sustainable Pavement \& Rail Initial Training Network) research project (http://superitn.eu/wp/) (Lo Presti et al., 2017). The SUP\&R ITN is a training-through-research programme, which through a multidisciplinary and multi-sectorial network, aims (1) to form a new generation of engineers versed in sustainable technologies for road pavement and railways and (2) to provide, to both academia and industry, design procedures and sustainability assessment methodologies to certify the sustainability of the studied technologies to the benefit of the European community. Some of the promising sustainable technologies developed and studied in the framework of this project are: (1) rubberised asphalt pavement wearing courses; (2) low-temperature asphalt mixes containing reclaimed asphalt pavement (RAP); (3) modified binders with tyre rubber and polymeric networks; (4) bituminous mixes manufactured with biomass; (5) rubberised asphalt for railways sub-ballast; (6) the use of waste materials in railways, etc.

Furthermore in the literature, other solutions have been mentioned as having the potential to improve pavement sustainability. They include (but are not limited to): (1) in-place pavement recycling (Thenoux et al., 2007; Robinette and Epps, 2010; Santos et al., 2015a); (2) pavement preservation strategies and preventive treatments (Giustozzi et al., 2012); (3) longlasting pavements (Lee et al., 2011; Sakhaeifar et al., 2013); (4) reclaimed asphalt shingles (RAS) materials (Illinois Interchange, 2012); (5) wearing course with very-high RAP content (Zaumanis and Mallick 2015; Lo Presti et al., 2016; Pires et al., 2017); (6) industrial wastes 
and byproducts (Birgisdóttir et al., 2006; Carpenter et al., 2007; Carpenter and Gardner, 2009; Huang et al., 2009; Lee et al., 2010; Sayagh et al., 2010; Mladenovič et al., 2015), etc.

\subsection{Sustainability assessment of road pavements}

The extent to which the solutions aforementioned can effectively be said to contribute to enhance pavement sustainability depends on the context in which they are applied, and on the way the sustainability is measured and evaluated. A common procedure adopted to measure and track the sustainability of transportation projects relies on rating systems (e.g., BE ${ }^{2} \mathrm{ST}$-inHighways $^{\mathrm{TM}}$ (Lee J.C. et al., 2011), Envision ${ }^{\mathrm{TM}}$ (Institute for Sustainable Infrastructure, 2012), Green Leadership in Transportation and Environmental Sustainability (GreenLITES) (NYSDOT, 2010), GreenPave (Lane et al., 2014), Greenroads (Muench et al., 2010), etc.). However, as pointed out by Simpson et al. (2014), there are desirable features generally lagging in transportation infrastructure rating systems, such as the choice of relevant criteria and the customizability of criteria. Additionally, aggregating all the indicators into a single score, practice commonly adopted in those rating systems, prevents decision-makers (DMs) from seeing the underlying performance across project sustainability objectives (Haider et al., 2016). Notwithstanding, choosing and judging between several alternatives and ultimately compromising on a solution requires understand the trade-offs between different criteria. Therefore, some sort of multi-criteria decision making (MCDM) method is needed to assist with that task.

By realizing this aspect, several attempts have been made recently to perform sustainability assessment of solutions intended to improve the sustainability of transportation projects. For instance, Kucukvar et al. (2014) developed a MCDM method which combines the Technique for Order of Preference by Similarity to Ideal Solution (TOPSIS) method and intuitionistic fuzzy sets and applied it for ranking the life cycle sustainability performance of different pavement alternatives constructed with hot mix asphalt (HMA) and WMA mixtures. Umer et al. (2017) developed a sustainability evaluation framework which address uncertainties in raw data during the planning phases by means of fuzzy set theory, and at the same time integrate life cycle assessment (LCA) and life cycle costs analysis (LCCA) results to compare different pavement alternatives, including asphalt, concrete and geosynthetics. Ozer et al. (2017) used a partial life cycle approach to assess the environmental and economic impacts of different pavement mixes and pay items. Batouli et al. (2017) performed LCA and LCCA analyses to investigate the sustainability of different pavement alternatives for a road extension project in Miami, Florida. Santos et al. (2017a) developed a MCDM framework which combines a comprehensive and integrated pavement LCC-LCA model and the TOPSIS method. The framework was used for ranking the life cycle sustainability performance of different pavement engineering solutions, namely hot in-plant recycling mixtures, WMA, cold central plant recycling (CCPR) and preventive treatments when applied either separately or in combination, in the construction and management of a road pavement structure.

\subsection{Aim and purpose of the study}

Despite the undeniable merits and achievements of the rating systems and studies mentioned in the previous sub-section, they tend to narrowly focus the sustainability assessment on the economic and environmental impacts of road pavement systems and technologies, thereby overlooking the third important dimension of sustainability, i.e. social impacts, as well as the trade-off between social, environmental and economic impacts. Even in the economic and environmental impacts assessment, several shortcomings can often and easily be pointed out. For instance, the system boundaries of the LCA performed to determine the environmental impacts disregard pavement life cycle phases, which depending on the features of the project, may have the potential to play a decisive role in the total environmental 
1 burdens (i.e., work zone traffic management and usage phase). Finally, they often limit the 2 analysis to the evaluation of the criteria and thereby do not provide insights on the ranking of the alternatives based on the relative importance of the criteria. Furthermore, in the specific case of the rating systems, the sustainability assessment is usually qualitative and doesn't provide the DM with numeric threshold that would allow performing less subjective choices.

Having detected this gap, this research study aims: (1) to develop a life cycle, sustainability performance-based, decision support system (DSS) which materializes the performance management framework envisioned in the scope of the SUP\&R ITN research project (Bryce et al., 2017) for helping DMs/stakeholders to prioritize alternative technologies adopted in the construction, maintenance and rehabilitation (M\&R) of transportation infrastructures; and (2) to show the applicability of the developed DSS by means of a practical exercise.

The overall purpose is to increase the DMs/stakeholders' capacity to make strategic and informed decisions regarding the construction and $M \& R$ of transportation infrastructures that would ultimately enhance the sustainability of transportation systems.

The research approach is organized as follows. Section 2 provides the theoretical background on MCDA methods. Section 3 describes the main features of the proposed sustainability-based DSS, including the MCDA framework and the sustainability indicators. Section 4 illustrates the capabilities of the proposed DSS through the application on a case study aiming at ranking pavement structures with different wearing courses for the road pavement. Finally, Section 5 concludes the paper.

\section{Background: Multi-criteria decision making methods}

MCDM is a branch of operation research approaches that tackle decision problems involving several decision criteria and alternatives. MCDM methods can be broadly classified into two main categories (Zavadskas et al., 2014): multi-attribute decision making (MADM) and multi-objective decision making (MODM). MADM methods are adopted to compare or rank a set of pre-defined alternatives based on their performances against a set of criteria. In turn, MODM techniques are employed to determine the set of optimal alternatives, unknown a-priori, which optimize a set of objective functions while subject to a set of well-defined design constraints.

Focusing on MADM, it has been in the spotlight of several areas as it pertains to sustainability-oriented decision making due to its capacity to methodically integrate environmental, social, and economic attributes, while helping to deal with the challenges of decision making under complex conditions that may involve contradictory, and not seldom incommensurate criteria, and numerous stakeholders with conflicting interests and priorities (Kiker et al., 2005; Huang et al., 2011; Reza et al., 2011; Mitropoulos and Prevedouros, 2014; Cinelli et al., 2014; Arce et al., 2015; Khishtandar et al., 2016; An et al., 2017; Cai et al., 2017). Furthermore, they promote the role of participants in decision making and provide a good platform for understanding the perception of models and analysts in a realistic scenario (Pohekar and Ramachandran, 2004).

Notwithstanding the existence in the literature of several classification theories (Linkov et al., 2004; Liou and Tzeng, 2012), in general, MADM methods can be divided into three main groups (Slowinski et al., 2002; Greco et al., 2004): (1) value-based methods; (2) outranking methods; and (3) decision rules theory.

The value-based methods include multi-attribute value theory (MAVT), multi-attribute utility theory (MAUT) (Keeney and Raiffa, 1993) and the analytic hierarchy process (AHP) (Saaty, 1988). In MAVT and MAUT, numerical scores are used to represent the merit of one alternative in comparison to others on a single scale. Scores are calculated from the performance of alternatives with respect to an individual criterion, after which the overall performance of one alternative is determined by aggregating the individual score of each 
1 criterion in a single overall score. MAUT quantifies individual's preferences, by creating utility 2 function, in order to facilitate trade-offs among several criteria. The main objective of MAVT 3 and MAUT is to maximize the overall utility considering the given preferences of DMs (Soltani 4 et al., 2015), which makes this a compensatory optimization approach. The main difference between MAVT and MAUT is that the latter explicitly considers uncertainty by using utility functions rather than value functions. The AHP method was developed by Saaty (1988) and evaluates alternatives using pairwise comparisons, by asking the DM his preference on a scale from 1 to 9 , in a multilevel hierarchic structure. This structures breaks down the decision from the top to the bottom, in which the goal is at the top level, criteria and sub-criteria are in middle levels, and the alternatives are at the bottom. Once the criteria weights and alternatives scores have been determined with the process summarily described above, the overall performance of the alternatives can be calculated by means of a linear additive model. The final result is a value in the range of $0-1$, where the weights indicate the trade-offs between the criteria (Cinelli et al., 2014).

Regarding the outranking methods, their rationale lays on performing comparisons between pairs (or more) of alternatives at a time, with respect to the criteria. The range of possible scores for different alternatives is considered within each criteria, to derive alternatives that can be combined across criteria. An alternative's relative score on a specific criterion is thus a function of how well it compares against the set of other alternatives (Huang et al., 2011). The most well-known methods belonging to this group are Preference Ranking Organization and Method for Enrichment Evaluation (PROMETHEE) (Brans and Vincke, 1985) and Elimination and Choice Expressing Reality (ELECTRE) (Roy, 1991).

Finally, the dominance-based rough set approach (DRSA) is a relatively new technique which can be employed in classification, choice and ranking problems. In DRSA methods, data tables are used, in which rows are defined as alternatives, while columns refer to the different condition attributes, specifically the criteria required to assess the alternatives and the decision attribute representing an overall evaluation of the alternative (Cinelli et al., 2014). Each cell of this table indicates an evaluation (quantitative or qualitative) of the alternative placed in that row by means of the attribute in the corresponding column. This table can be seen as a set of decision rules, in the form of "if...then ..." connecting condition and decision criteria (Slowinski et al., 2009).

\section{Methodology}

The methodology of the proposed sustainability-based DSS follows the diagram presented in Figure 1 and is described in the sub-sections below. It comprises the following stages: (1) selection of the environmental, economic and social indicators to be adopted for sustainability assessment; (2) definition of the alternatives to be compared and evaluation matrix formulation; (3) definition of the decision-making matrix, which includes the specification of the weights to be assigned to each indicator and the assessment of the performance of each alternative with regard to each indicator; (4) performance of the MCDA to rank the sustainability of the finite number of alternatives; and (5) sensitivity analyses of important input parameters and alternatives' scores to determine their impact on the ranking of the alternatives. 

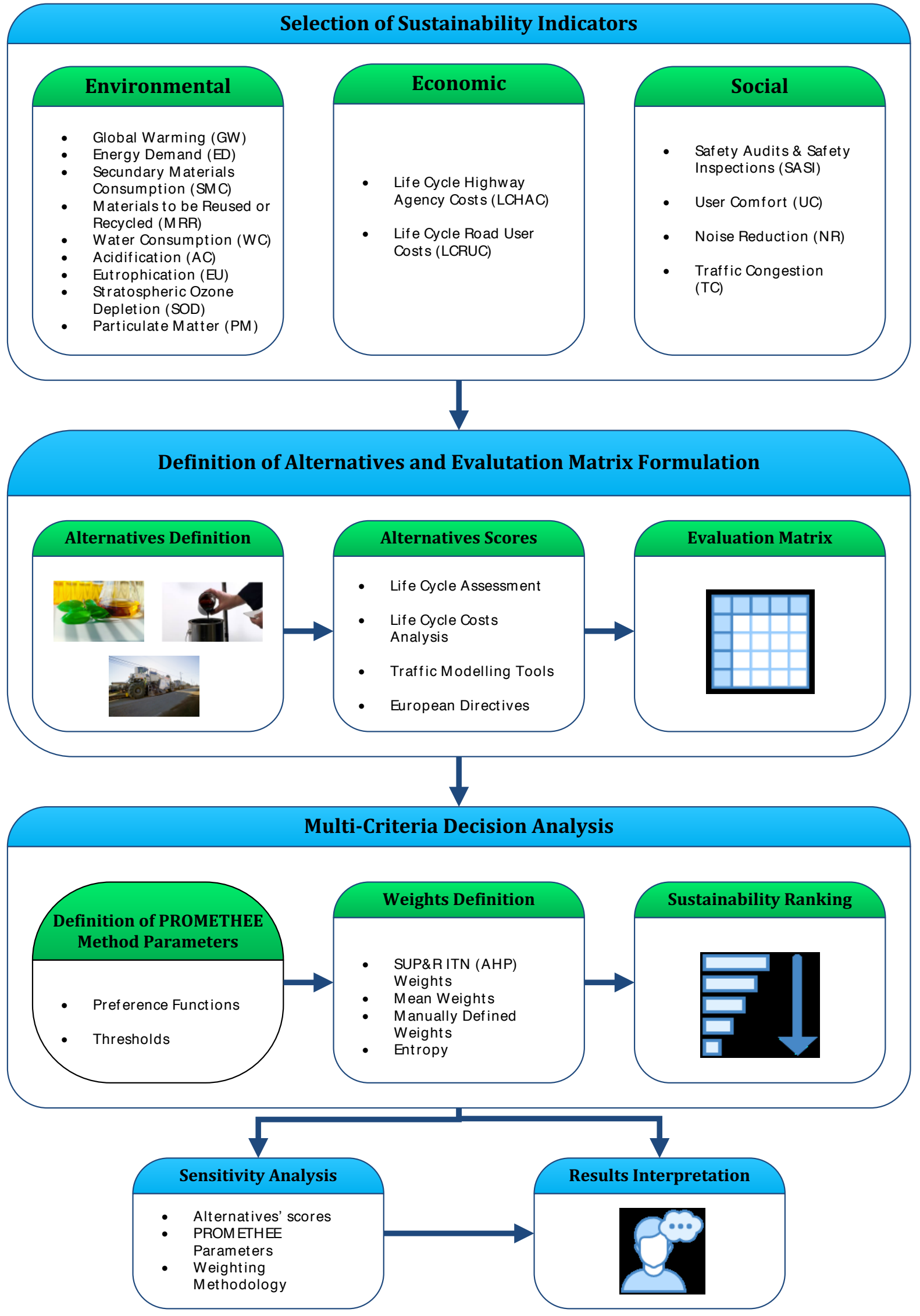

Figure 1. Sustainability-based decision support system framework for road pavements. 


\subsection{Sustainability indicators}

Defining appropriate indicators that consistently measure sustainability of alternative technologies is of paramount importance and should be context sensitive. Then, the proposed sustainability-based DSS incorporates, by default, the indicators defined according to the methodology developed in the framework of the SUP\&R ITN research project for transportation systems. It builds upon the DPSIR (driver, pressure, state, impact, response) framework developed by the European Environmental Agency and adapted by Bryce et al. (2017). Succinctly, it comprises four steps employing different criteria with the ultimate objective of deriving a set of indicators that maximize their significance to the principles of sustainability applied to transportation systems. This is undertaken while covering a large spectrum of aspects related to the three Wellbeing dimensions (i.e. social, environmental and economic) and also taking into account the outcomes of recent and relevant research project in the field (i.e., LCE4Roads (http://www.lce4roads.eu/)) and pre-standardization procedures (i.e., CEN/CENELEC Workshop Agreement (CWA) on SUSTINROADS). A wide and detailed explanation on the methodology developed to select the set of indicators will be published elsewhere and soon freely available on http://superitn.eu. Hereafter, for the sake of brevity only a concise description of that methodology as well as of each indicator belonging to the final set is presented in this section.

\subsubsection{Indicators selection methodology}

Initially, an extensive literature review was performed to identify the criteria and indicators that have been used to measure the sustainability of road pavement and railways projects. The indicators collected were posteriorly screened according two set of criteria: (1) measurability, unique and globally accepted definition and recurrence; and (2) sensitivity, updatable data, available data, and non-corruptibility. Next, each indicator was given a score based on a three-point scale (i.e., 0,1 and 2 points) for each criterion and those that were given a score of zero in any of the individual criteria aforementioned were automatically excluded from the list of candidate indicators. The retained indicators were posteriorly reorganized to understand how they could be applied across the lifecycle of a road and rail project based on the different phases characterizing it. In the next step, the third quartile $\left(75^{\text {th }}\right.$ percentile $)$ of the recurrence of the indicators still eligible was calculated and any indicator with a recurrence value inferior to that value was considered not to qualify for inclusion in the final list of indicators. Finally, in the last step, the eligible indicators were subject to a critical judgment that would determine their fate with regard to the inclusion in the final short-list. Complementarily, the indicators excluded throughout the selection process were given the possibility of being taken up in face of well justified reasons.

\subsubsection{Environmental indicators}

\subsubsection{Global warming indicator $(G W)$}

This indicator refers to the impact of human emissions, namely GHG, on the radiative forcing (i.e. heat radiation absorption) of the atmosphere, causing the temperature at the earth's surface to rise. It is measure in terms of $\mathrm{kg} \mathrm{CO}_{2}$-eq.

\subsubsection{Energy demand (ED)}

This indicator refers to the amount of energy required for undertaking the processes underlying to the construction, maintenance and rehabilitation (M\&R), use and end-of-life (EOL) of the road pavement. It is expressed in MJ and will be quantified through the Cumulative Energy Demand (CED) indicator (Frischknecht et al., 2015). This indicator represents a measure of direct and indirect energy use over the entire life cycle of a product, including the conversion efficiencies. It accounts for energy produced from non-renewable 
1 sources (fossil, nuclear, and non-renewable biomass) and renewable sources (wind, solar, 2 geothermic, hydro, and renewable biomass).

3

4

5

6

\subsubsection{Secondary materials consumption (SMC)}

This indicator refers to the amount of the recycled materials used in the project as material recovered from previous use or from waste which substitutes primary materials. It is measured in terms of the percentage (\%) of recycled materials used related to the total material consumption. Alternatively this indicator can be expressed in mass unit.

\subsubsection{Materials to be reused or recycled (MRR)}

This indicator refers to the amount of waste materials or excess quantity of materials used in the project that has potential to be recycled at the end of life stage instead of being landfilled. It is measured in terms of the percentage (\%) of recyclability and the percentage (\%) of reusability (related to the total material sum) that could be re-used and recycled in the future. Similarly to the previous indicator, it can also be expressed in mass unit.

\subsubsection{Water consumption (WC)}

This indicator refers to the amount of water used for undertaking the processes underlying to the construction, M\&R and EOL of the road pavement (i.e., either remain in place or be removed). It is measured in terms of $\mathrm{m}^{3}$ of water consumed.

\subsubsection{Acidification indicator of soil and water $(A C)$}

This indicator refers to the increase of the acidity of water and soil systems by $\mathrm{H}^{+}$ concentration. This alters the $\mathrm{pH}$ of that environment, which may cause damage to the organic and inorganic materials. It is measured in terms of $\mathrm{kg} \mathrm{SO}_{2}$-eq.

\subsubsection{Eutrophication indicator (EU)}

This indicator refers to the impacts caused by the excessive levels of macronutrients (nitrogen $(\mathrm{N})$ and phosphorous $(\mathrm{P})$ ) in the environment due to the emissions of nutrients to air, water and soil. This may cause an elevated biomass production. It is measured in terms of $\mathrm{kg}$ $\mathrm{PO}_{4}{ }^{3-}$-eq.

\subsubsection{Stratospheric ozone depletion indicator (SOD)}

This indicator addresses the thinning of the stratospheric ozone layer as a result of anthropogenic emissions, mainly chlorofluorocarbon (CFC) compounds. It is measured in terms of kg CFC-11-eq.

\subsubsection{Particulate matter indicator (PM)}

This indicator refers to the amount of suspended particles with a diameter of less than 10 $\mu \mathrm{m}\left(\mathrm{PM}_{10}\right)$ originated from anthropogenic processes such as combustion, resource extraction, etc., that may induce several health problems, especially of the respiratory tract. It is measured in terms of $\mathrm{kg} \mathrm{PM}_{10}$-eq.

\subsubsection{Social indicators}

\subsubsection{Safety audits \& safety inspections (SASI)}

This indicator refers to the verification of the accomplishment of the road safety audits (RSA) and inspections (RSI) as required by the European Directive 2008/96/EC on road infrastructure safety management. It is measured qualitatively (Yes or No) by answering to the question "Was the RSA or RSI report issued?" 


\subsubsection{User comfort (UC)}

This indicator evaluates the road user's level of comfort relatively to the travelled roadway. It is measured as the area under the Present Serviceability Index (PSI) curve or the area under the curve representing the pavement roughness, expressed through the International Roughness Index (IRI). The PSI is a mathematical model developed based on the mean roughness of a pavement, rated on a scale from 0 to 5 by a panel of passengers driving over the pavement in a vehicle. In turn, the IRI is an objective measurement of pavement roughness and can be obtained using vehicle-mounted high-speed inertial profilers, after applying a mathematical model to calculate it as the vehicle's suspension displacement per unit of distance travelled, expressed in unit of slope $(\mathrm{m} / \mathrm{km})$.

\subsubsection{Noise reduction (NR)}

This indicator refers to the reduction of the noise level in order to decrease the acoustic impact on the users and surrounding populations. It is measured in decibel (dB).

\subsubsection{Traffic Congestion (TC)}

This indicator refers to the traffic congestion caused by to the execution of pavement M\&R activities. It is measured as the additional road users travel time (hours).

\subsubsection{Economic indicators}

\subsubsection{Life cycle highway agency costs (LCHAC)}

This indicator comprises the total costs incurred by the highway or transportation agency over the life of the project to construct and maintaining a pavement structure above a determined quality level. They typically include initial costs (e.g., preliminary engineering, contract administration, supervision and construction costs) and future costs (i.e., M\&R costs and the EOL fate-related costs) (Santos et al., 2017b). The data required to determine the agency costs are usually obtained from historical records, current bids, and engineering judgments.

\subsubsection{Life cycle road user costs (LCRUC)}

This indicator comprises the marginal costs incurred by the road user due to the increase of the fuel consumption as a consequence of the deterioration of the pavement condition throughout its life cycle, as well as the traffic perturbations caused by the execution of the M\&R activities.

\subsection{Definition of alternatives and evaluation matrix formulation}

Once the alternatives have been defined, their performance with regard to each indicator is assessed by employing mostly life cycle-based methodologies. In this regard, the LCA is used for estimating the majority of the environmental indicators, whereas the LCCA is adopted to quantify the economic indicators. Finally, the social indicators are evaluated on the basis of traffic modelling tools and methodologies developed in the scope of European directives, namely the Directive 2008/96/EC on road infrastructure safety management (Directive 2008/96/EC, 2008). Excepting the case of a few indicators for road pavements (i.e., Safety audits \& safety inspections and Noise reduction), which are supposed to be quantified according to European Directives, the SUP\&R ITN methodology does not specify methods or tools for quantifying the indicators, given that different users will have their own preferences. Some methodologies/tools are, however, suggested in Table 1. 
1 Table 1. Some suggested methodologies/tools for the assessment of the indicators.

\begin{tabular}{ll}
\hline Indicator & Methodologies/tool \\
\hline Global warming indicator & Life cycle impact assessment (LCIA) methods implemented in \\
Energy demand & LCA tools, such as SimaPro, OpenLCA, GaBi ${ }^{1}$ \\
Secondary materials consumption & Cumulative Energy Demand (CED) \\
\hline Baterials to be reused or recycled & 2 \\
Water consumption & Water depletion \\
\hline Acidification indicator of soil and water & 1 \\
Eutrophication indicator & 1 \\
Ozone depletion indicator & 1 \\
\hline Particulate matter & 1 \\
Safety audits \& safety inspections & $\begin{array}{l}\text { European Directive 2008/96/EC on road infrastructure safety } \\
\text { management }\end{array}$ \\
User comfort & $\begin{array}{l}\text { Area above or below the pavement performance prediction } \\
\text { model, depending on its monotony }\end{array}$ \\
\hline & CNOSSOS-EU method for strategic noise mapping following \\
Noise reduction & adoption \\
Traffic congestion & as specified in the Environmental Noise Directive 2002/49/EC \\
\hline Life cycle highway agency Costs & HCM, RealCost, QUADRO, Visum \\
(LCHAC) & Bids, authorities guidelines \\
Life cycle road user costs (LCRUC) & Fuel costs: Swedish National Road and Transport Research \\
\hline
\end{tabular}

\subsection{Multi-criteria decision analysis (MCDA)}

\subsubsection{The PROMETHEE-II method}

In order to rank each alternative based upon its sustainability level, the proposed DSS implements an outranking MADA method, namely the PROMETHEE-II method.

An outranking approach was selected because of its non-compensatory nature, in the sense that a bad performance on an indicator cannot be compensated with a good performance on another indicator. According to Munda (2005), complete compensability is not desirable in a method for tackling sustainability decision problems. The rationale underlying to this statement lays on the concept of "strong sustainability". According to this concept, natural capital is a set of complex systems, evolving interacting abiotic and biotic elements, whose consumption is irreversible and irreplaceable by manufactured capital and thus, no trade-offs are admissible. This concept contrasts with that of "weak sustainability", according to which natural capital and manufactured capital are substitutable and no essential differences exist between the kinds of well-being they generate (Ekins et al., 2003). Therefore, in view of the implementation of the concept of "strong sustainability", which constraint or abolish the compensation among sustainability dimensions, outranking approaches should be preferred to performance aggregation-based approaches.

Finally, as for the PROMETHEE-II method, its selection was driven by the following facts: (1) it is one of the best known outranking methods (Sultana and Kumar, 2012), with an applicability level extended to multiple domains (Behzadian et al., 2010); (2) it has a transparent computational procedure which can incorporate both quantitative and qualitative data; (3) it requires fewer parameters from the DM when compared to other outranking methods, such as the ELECTRE (Betrie et al., 2013); and (4) the comparison of the alternatives can be performed without difficulty, producing results that consist of a ranking and the identification of the best alternative, and thereby are of easy understanding for any $\mathrm{DM} /$ stakeholder, regardless of its expertise level. 
In this outranking method, alternatives are compared pairwise on the basis of every single indicator. Let $A$ be a set of alternatives for ranking and $G$ be the total number of criteria (indicators). PROMETHEE method considers a function $P_{j}(a, b)$, that is a function of the difference $\left(d_{j}\right)$ between the scores of two alternatives for every criterion $\left(g_{j}\right)$, in which the difference is calculated as $d_{j}(a, b)=g_{j}(a)-g_{j}(b)$. Brans and Mareschal (2005) defines six different functions to model the preferences of the DM. Some preference function (PF) may require a predetermined preference threshold $(p)$ or indifference threshold $(q)$ or both. The indifference threshold, $q$, represents the largest deviation which is considered as negligible by the DM. The preference threshold, $p$, represents the smallest deviation which is considered as sufficient to generate a total preference. Once $P_{j}(a, b)$ have been computed, and considering the weight assigned to criterion $j\left(w_{j}\right)$, the values are converted into the multi-criteria index, $\pi(a, b)$, that expresses the degree to which $a$ is preferred to $b$ over all the criteria, as described in the Equation (1):

$$
\left\{\begin{array}{l}
\pi(a, b)=\sum_{j=1}^{G} P_{j}(a, b) \times w_{j} \\
\pi(a, b)=\sum_{j=1}^{G} P_{j}(b, a) \times w_{j}
\end{array}\right.
$$

where $\pi(a, b)$ can assume values between 0 and 1 , and the greater the value of $\pi(a, b)$, the greater the preference of $a$ over $b$. Furthermore, $\pi(a, b) \approx 0$ implies a weak global preference of $a$ over $b$, while $\pi(a, b) \approx 1$ implies a strong global preference of $a$ over $b$ (Brans and Mareschal, 2005).

In order to compare an alternative $a$ with all the other alternatives of the set $A$, PROMETHEE method considers the positive $\left(\phi^{+}(a)\right)$ and negative $\left(\phi^{-}(a)\right)$ flow of $a$ defined as follows (Equation (2)):

$$
\begin{aligned}
& \phi^{+}(a)=\frac{1}{1-n} \sum_{x \in A} \pi(a, x) \\
& \phi^{-}(a)=\frac{1}{1-n} \sum_{x \in A} \pi(x, a)
\end{aligned}
$$

Each alternative $a$ is compared with (n-1) other alternatives in $A$. The positive flow measures how much alternative $a$ is dominating the others, and thus, the higher the value of the positive flow, the better the alternative. In turn, the negative flow denotes how much alternative $a$ is dominated by the others, and thus, the lower the value of the negative flow, the better the alternative. The final ranking is calculated by sorting the alternatives based on its net flow, $\phi(a)$, calculated according to Equation (3):

$$
\phi(a)=\phi^{+}(a)-\phi^{-}(a)
$$

The net flow, $\phi(a)$, is the balance between the positive and the negative flows, and the higher the net flow, the better the alternative.

\subsubsection{Weighting methodologies}

The weight of an indicator is a measure of how much it is important with respect to the other indicators. The SUP\&R ITN MCDA methodology comprises two weighting approaches: subjective and objective. Furthermore, each approach features two alternative weighting methods. The subjective approach determine the weights of the indicators based exclusively 
on preference information of indicators provided by the DM, whereas in the objective approach weights are determined by employing mathematical models without any consideration of the DM's preferences.

The objective methods considered in the SUP\&R ITN MCDA methodology include the Entropy and the Mean weight methods. In information theory, entropy is used to refer to a general measure of uncertainty. It can also measure the amount of useful information that can be obtained from the data. Thus, when the evaluated alternatives have a great difference between each other on a particular indicator, the entropy is smaller, meaning that the indicator provide more effective information, and therefore the its weight should be larger. On the contrary, when the differences are smaller, the entropy is larger, which shows that the amount of information provided by the indicator is smaller, and therefore its weight should be correspondingly smaller. In turn, according to the Mean weight method all the indicators are equally important, and therefore are given the same weight.

As for the weighting methods belonging to the subjective approach, the SUP\&R ITN MCDA methodology gives the DM the possibility of considering its own weighting set, hereafter named Manually defined weighting set. Alternatively, it provides a weighting set derived from an Analytical Hierarchical Process (AHP)-based survey conducted in the framework of the SUP\&R ITN research project. Public/institutional representative from the public administration, self-employed professional, universities, enterprises and other social agents across academia, industry and consulting companies were invited to respond to a survey that was available on-line during approximately two months. In the total 52 individuals contributed to derive the weighting set hereafter named SUP\&R ITN weighting set.

\subsection{Sensitivity analysis}

To test the robustness of the MCDA results, sensitivity analysis should be undertaken to ascertain if and how the ranking of the alternatives varies in face of changes of important input parameters.

\section{Case study: description and results}

In this section, the proposed sustainability-based DSS was applied for selecting the most sustainable road pavement construction and maintenance scenario, in which innovative asphalt mixtures are laid down in the wearing coarse of the flexible road pavement of a typical French highway section of 1-km length, composed of two independent roadways, each with two lanes with an individual width of $3.5 \mathrm{~m}$. The sustainability evaluation of each alternative was performed according to a life cycle approach, for a project analysis period (PAP) of 30 years, starting in 2015, and considering all phases of the pavement life cycle, namely raw material extraction and mixtures production, construction and $M \& R$, work-zone (WZ) traffic management, usage and EOL phase. The initial two-way average annual daily traffic (AADT) was considered to be equal to 6500 vehicles/day, of which $33 \%$ are heavy duty vehicles (HDV) (equality divided between rigid HDV and articulated HDV). The structure and composition of the French fleet of vehicles, expressed in terms of type of vehicles and European emissions standards, was that defined by CITEPA (Centre Interprofessionnel Technique d'Études de la Pollution Atmosphérique). The traffic growth rate was 1.5\% per year (Jullien et al., 2015). The geometric characteristics of the pavement structure adopted in each of the independent roadways are presented in Figure 2.

As for pavement maintenance, a pavement M\&R strategy derived from French practice was considered (Jullien et al., 2014; Jullien et al., 2015). The maintenance tasks inherent to each M\&R activity, as well as the application timing are displayed in Figure 2. 


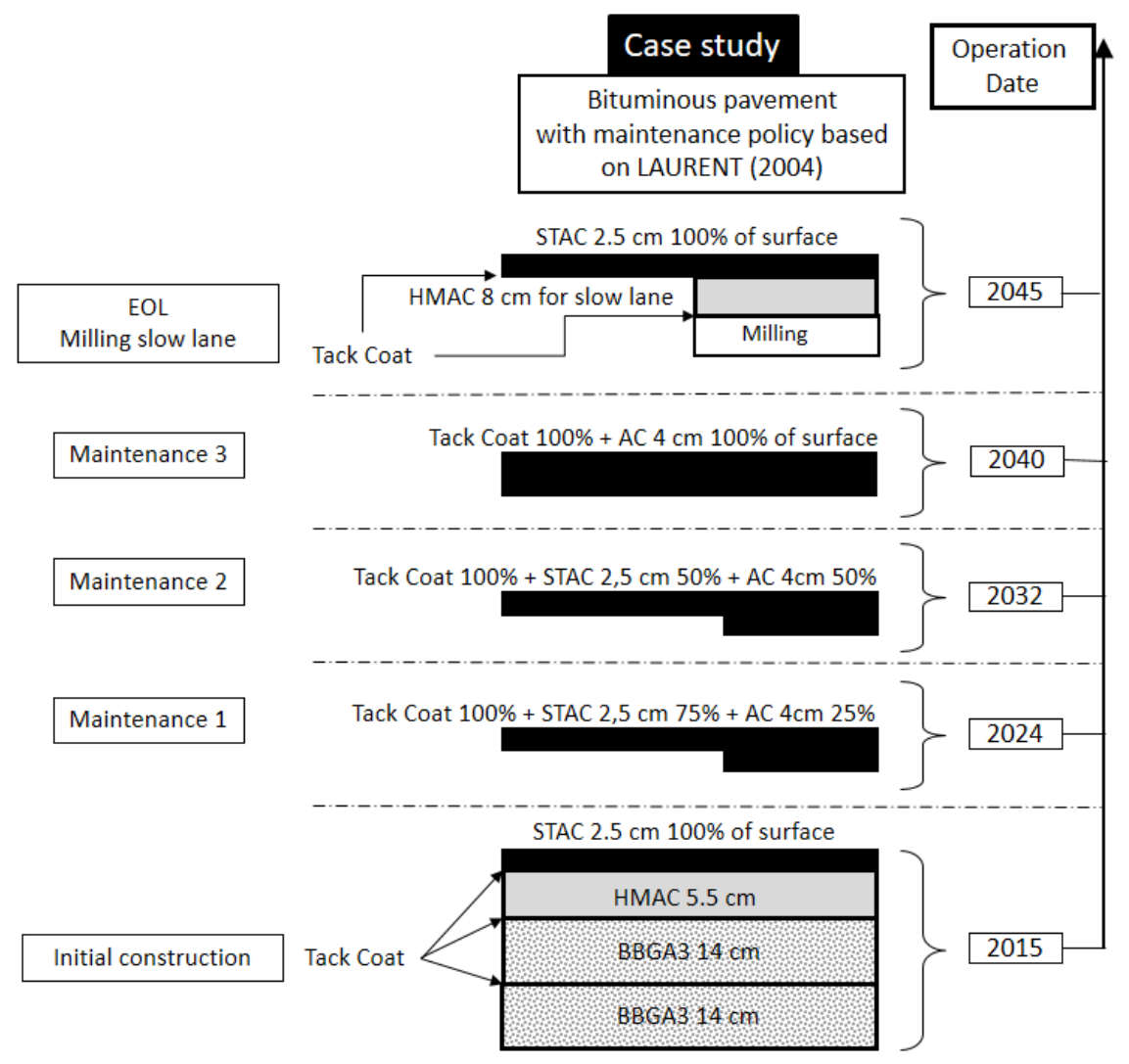

Figure 2. Geometric characteristics of the flexible pavement structure and M\&R strategy. (Acronyms: BBGA- bituminous bound graded aggregate; HMAC - hot mix asphalt concrete; STAC-super thin asphalt concrete; $\mathrm{AC}$ - asphalt concrete).

\subsection{Sustainability indicators}

The sustainability indicators considered in this case study are those presented in Section 3.1, excepting the MRR, SASI, UC and NR. These indicators were disregarded based on: (1) the features of the materials employed in the case study (concerning the MRR indicator), as well as its technical context (concerning the SASI indicator); (2) research studies showing that HMA and WMA pavements have comparable long-term field performance in terms of structural durability (Washington State University et al., 2017) (concerning mainly the UC indicator); (3) the assumption that initial surface properties (e.g., macrotexture) are the same for all mixtures (concerning the NR indicator); (4) inexistence of solid scientific evidences that functional properties of HMA and WMA pavements will evolve distinctively over time (concerning the UC and NR indicators). Therefore, the scores of the alternatives with regard to each one of the indicators listed above do not vary.

The midpoint level life impact assessment (LCIA) method CML 2001 (Guinée et al., 2002) was adopted to quantify the following environmental indicators: GW, AC, EU, SOD. The ED indicator was calculated according to the definition of CED (also called "primary energy consumption") specified by Hischier et al. (2010). In turn, the hierarchist variant of the ReCiPe midpoint LCIA method (Goedkoop et al., 2013) was adopted to calculate the PM and WC indicators. Finally, the SMC indicator was quantified according to the formulation of the mixtures, namely the RAP content.

Regarding the economic indicators, the LCHAC were determined on the basis of the data representative of the general French conditions provided by a French construction company. The marginal fuel consumption costs incurred by the road users during the WZ traffic management and usage phases were calculated by considering, respectively, the following 
gasoline without plumb 95 and diesel unit costs (values for 2015): $1.42 € /$ litre and $1.15 € /$ litre (Ministère de la Transition Écologique et Solidaire, 2017).

As far as the social indicators are concerned, the TC indicator was quantified by applying the capacity and delay models proposed by the HCM 2000 method (TRB, 2000).

\subsection{Definition of alternatives and quantification of the evaluation matrix}

The reference pavement structure (Figure 2) constituted by layers made of conventional HMA without RAP content was compared to four alternative structures with equal geometry, but in which the wearing course of the initial structure, and subsequent M\&R treatments, was made of WMA.

WMA represents a broad range of technologies used with asphalt concrete that allow the mixture to be produced, stay workable and compactable at lower temperatures than typical HMA. The WMA temperature reduction can be obtained by means of several technologies that involve the use of organic additives, chemical additives, and water-based or water-containing foaming processes (Rubio et al., 2012)

In this case study, the WMA was produced according with two different technologies (i.e., foaming and CECABASE ${ }^{\circledR}$ additive) and with and without the adding of a RAP content of $50 \%$. Furthermore, the set of alternative mixtures was completed with the consideration a conventional HMA with a RAP content of $50 \%$, thus rising to 6 the total number of pavement sections to be analysed and compared. The features of the several mixtures analyzed in the case study are shown in Table 2.

The score of the alternatives with respect to each indicator is presented in Table 3. Details on the features of the system boundaries of the case study as well as the assumptions considered can be found in Santos et al. (2017c).

Table 2. Summary of the features of the HMA and WMA mixtures used in the conventional and alternative scenarios.

\begin{tabular}{|c|c|c|c|c|c|c|}
\hline \multirow[b]{2}{*}{ Item } & \multicolumn{6}{|c|}{ Type of mixture } \\
\hline & $\begin{array}{l}\text { HMA, } 0 \% \\
\text { RAP }\end{array}$ & $\begin{array}{l}\text { WMA- } \\
\text { CECABASE }^{\circledR}, \\
0 \% \text { RAP }\end{array}$ & $\begin{array}{l}\text { Foamed } \\
\text { WMA, 0\% } \\
\text { RAP }\end{array}$ & $\begin{array}{l}\text { HMA, } \\
50 \% \\
\text { RAP } \\
\end{array}$ & $\begin{array}{l}\text { WMA- } \\
\text { CECABASE }^{\circledR}, \\
50 \% \text { RAP }\end{array}$ & $\begin{array}{l}\text { Foamed } \\
\text { WMA, } \\
50 \% \text { RAP }\end{array}$ \\
\hline \multicolumn{6}{|l|}{ Virgin aggregate } & 48.36 \\
\hline $\begin{array}{l}\text { Water content } \\
(\% / a)\end{array}$ & 3 & 3 & 3 & 3 & 3 & 3 \\
\hline \multicolumn{7}{|l|}{$R A P$} \\
\hline Quantity (\%/m) & - & - & - & 48.4 & 48.37 & 48.36 \\
\hline $\begin{array}{l}\text { Water content } \\
(\% / \text { RAP })\end{array}$ & - & - & - & 3 & 3 & 3 \\
\hline \multicolumn{7}{|l|}{ Bitumen } \\
\hline Penetration grade & $35 / 50$ & $35 / 50$ & $35 / 50$ & $35 / 50$ & $35 / 50$ & $35 / 50$ \\
\hline Quantity $(\% / \mathrm{m})$ & 5.4 & 5.4 & 5.4 & 3.2 & 3.2 & 3.2 \\
\hline \multicolumn{7}{|l|}{ WMA agent } \\
\hline Type & - & surfactant & water & - & surfactant & water \\
\hline Quantity $(\% / \mathrm{m})$ & - & 0.054 & 0.077 & - & 0.054 & 0.077 \\
\hline $\begin{array}{l}\text { Mixture density } \\
\left(\mathrm{kg} / \mathrm{m}^{3}\right)\end{array}$ & 2360 & 2340 & 2260 & 2370 & 2360 & 2360 \\
\hline
\end{tabular}


1 Table 3. Evaluation matrix.

\begin{tabular}{|c|c|c|c|c|c|c|c|c|c|c|c|c|}
\hline \multicolumn{2}{|c|}{ Alternative scenario } & \multicolumn{11}{|c|}{ Sustainability indicators } \\
\hline ID & Name & $\begin{array}{l}\mathrm{GW}(\mathrm{Kg} \\
\mathrm{CO}_{2} \text {-eq) }\end{array}$ & $\mathrm{ED}(\mathrm{MJ})$ & $\begin{array}{l}\text { SMC } \\
(\%) \\
\end{array}$ & $\begin{array}{l}\mathrm{WC} \\
\left(\mathrm{m}^{3}\right) \\
\end{array}$ & $\begin{array}{l}\mathrm{AC}(\mathrm{kg} \\
\left.\mathrm{SO}_{2}-\mathrm{eq}\right) \\
\end{array}$ & $\begin{array}{l}\mathrm{EU}(\mathrm{kg} \\
\left.\mathrm{PO}_{4}-\mathrm{eq}\right)\end{array}$ & $\begin{array}{l}\text { SOD (kg } \\
\left.\mathrm{CHC}_{11-\mathrm{eq}}\right) \\
\end{array}$ & $\begin{array}{l}\text { PM (kg } \\
\left.\text { PM }_{10}-\mathrm{eq}\right)\end{array}$ & $\begin{array}{l}\text { TC } \\
(\mathrm{Hr}) \\
\end{array}$ & $\begin{array}{l}\text { LCHAC } \\
(€)\end{array}$ & $\begin{array}{l}\text { LCRUC } \\
(€)\end{array}$ \\
\hline 1 & $\begin{array}{l}\text { HMA, 0\%RAP } \\
\text { WMA- }\end{array}$ & 1257898 & 69679068 & 0 & 2424 & 10376 & 4513 & 0.823 & 2871 & 46.142 & 1266306 & 2145 \\
\hline 2 & $\begin{array}{l}\text { CECABASE }^{\circledR}, \\
0 \% \text { RAP }\end{array}$ & 1236348 & 69442583 & 0 & 4123 & 10221 & 4495 & 0.818 & 2847 & 40.921 & 1270296 & 2042 \\
\hline 3 & $\begin{array}{l}\text { Foamed WMA, } \\
0 \% \text { RAP }\end{array}$ & 1223723 & 68680490 & 0 & 2399 & 10117 & 4431 & 0.811 & 2809 & 40.921 & 1259028 & 2042 \\
\hline 4 & $\begin{array}{l}\text { HMA, } 50 \% \text { RAP } \\
\text { WMA- }\end{array}$ & 1202024 & 63620766 & 11 & 2234 & 9788 & 4273 & 0.750 & 2713 & 46.142 & 1204773 & 2145 \\
\hline 5 & $\begin{array}{l}\text { CECABASE }^{\circledR}, \\
50 \% \text { RAP }\end{array}$ & 1181481 & 63536209 & 11 & 3936 & 9645 & 4259 & 0.748 & 2691 & 40.921 & 1209036 & 2042 \\
\hline 6 & $\begin{array}{l}\text { Foamed WMA, } \\
50 \% \text { RAP }\end{array}$ & 1178377 & 63380866 & 11 & 2232 & 9630 & 4248 & 0.748 & 2679 & 40.921 & 1203225 & 2042 \\
\hline
\end{tabular}

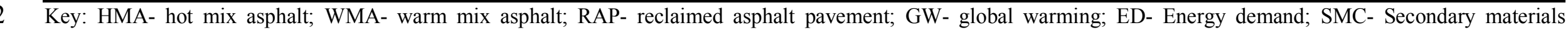

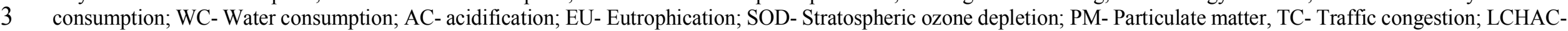
Life cycle highway agency costs; LCRUC- Life cycle road user costs. 


\subsection{Multi-criteria decision analysis (MCDA)}

In this section the alternatives described previously are ranked by applying the PROMETHEEII method. However, before using that outranking method, for each indicator, a specific PF with its thresholds as well as a weight value have to be defined. Six main types of PF can be found in the literature (Brans and Vincke, 1985): (1) usual, (2) U-shape, (3) linear, (4) level, (5) V-shape with linear preference and indifference area, and (6) Gaussian. In this case study, the $V$-Shape with linear preference and indifference area PF was selected for all indicators based on the authors' judgment as well as on the insights acquired from other studies (Geldermann and Rentz, 2005; Podvezko and Podviezko, 2010; Kilic et al., 2015; Dražić et al., 2016; Schmitt et al., 2017).

As it pertains to the thresholds values selection, no strict rule exist to govern it. However, divers research studies (e.g., Geldermann and Rentz, 2005; Gervásio and Simões da Silva, 2012; Carbone et al., 2014; Schmitt et al., 2017) adopt the Podvezko and Podviezko (2010)'s recommendation, according to which the preference $(p)$ and indifference $(q)$ thresholds should be between the minimum and the maximum of the differences observed within the indicators' scores.

Following the current practice adopted in the literature, in this case study the $p$ values were defined in such way that they amount to $65 \%$ of the difference between the highest and lowest score for each indicator $\left(d_{j}^{p}\right)$, whereas the $q$ values were defined as $5 \%$ of the difference between the highest and lowest score for each indicator $\left(d_{j}^{q}\right)$. A sensitivity analysis for $q$ and $p$ values was however performed and discussed in next section to ascertain their influence on the stability of the rankings (Rogers and Bruen, 1998).

Finally, the SUP\&R ITN weighting set was adopted to weight the several indicators. The thresholds and weight values defined for each indicator are summarized in Table 4.

Table 4. Weights, preference functions and thresholds considered for each indicator.

\begin{tabular}{|c|c|c|c|c|}
\hline \multirow{2}{*}{$\begin{array}{l}\text { Sustainability } \\
\text { indicator }\end{array}$} & \multirow{2}{*}{$\begin{array}{l}\text { Weight } \\
(\%)\end{array}$} & \multicolumn{3}{|l|}{ Preference Function } \\
\hline & & Type & $p$ & $q$ \\
\hline GW & 3.17 & $\begin{array}{l}\text { V- Shape with linear preference and indifference } \\
\text { area }\end{array}$ & 51688.65 & 3976.05 \\
\hline ED & 3.29 & $\begin{array}{l}\text { V- Shape with linear preference and indifference } \\
\text { area }\end{array}$ & 4093831.30 & 314910.10 \\
\hline SMC & 4.75 & $\begin{array}{l}\text { V-Shape with linear preference and indifference } \\
\text { area }\end{array}$ & 7.15 & 0.55 \\
\hline $\mathrm{WC}$ & 15.12 & $\begin{array}{l}\text { V- Shape with linear preference and indifference } \\
\text { area }\end{array}$ & 1229.15 & 94.55 \\
\hline $\mathrm{AC}$ & 4.08 & $\begin{array}{l}\text { V- Shape with linear preference and indifference } \\
\text { area }\end{array}$ & 484.90 & 37.30 \\
\hline EU & 4.08 & $\begin{array}{l}\text { V- Shape with linear preference and indifference } \\
\text { area }\end{array}$ & 172.25 & 13.25 \\
\hline SOD & 4.08 & $\begin{array}{l}\text { V- Shape with linear preference and indifference } \\
\text { area }\end{array}$ & 0.04875 & 0.00375 \\
\hline PM & 30.90 & $\begin{array}{l}\text { V- Shape with linear preference and indifference } \\
\text { area }\end{array}$ & 124.80 & 9.60 \\
\hline $\mathrm{TC}$ & 20.76 & $\begin{array}{l}\text { V- Shape with linear preference and indifference } \\
\text { area }\end{array}$ & 3.39 & 0.26 \\
\hline LCHAC & 4.89 & $\begin{array}{l}\text { V- Shape with linear preference and indifference } \\
\text { area }\end{array}$ & 43596.15 & 3353.55 \\
\hline LCRUC & 4.89 & $\begin{array}{l}\text { V- Shape with linear preference and indifference } \\
\text { area }\end{array}$ & 66.95 & 5.15 \\
\hline
\end{tabular}


matter, TC- Traffic congestion; LCHAC- Life cycle highway agency costs; LCRUC- Life cycle road user costs; $p$ - preference threshold; $q$ - indifference threshold.

The positive $\left(\phi^{+}\right)$, negative $\left(\phi^{-}\right)$and net $(\phi)$ flows, as well as the consequent ranking of each alternative are shown in Figure 3. From the analysis of this figure it can be seen that the construction and M\&R scenario in which the mixture foamed WMA with $50 \%$ RAP is employed in the surface course ranks first, followed by the mixture WMA-CECABASE ${ }^{\circledR}$ additive with 50\%RAP and the mixture HMA with 50\%RAP. In turn, the construction and M\&R scenario that adopts the mixture conventional HMA was found to be the least sustainable. The fact that the mixture foamed WMA with $50 \%$ RAP is the most sustainable option is not a surprise due to its better performance on all indicators, as denoted by Table 3. This result is also proved by its null negative flow. Another result worthy of mention is the fact that a mixture HMA with $0 \%$ RAP is more sustainable than any WMA mixture with $0 \%$ RAP, regardless of the technology used for lowering the manufacturing temperature.

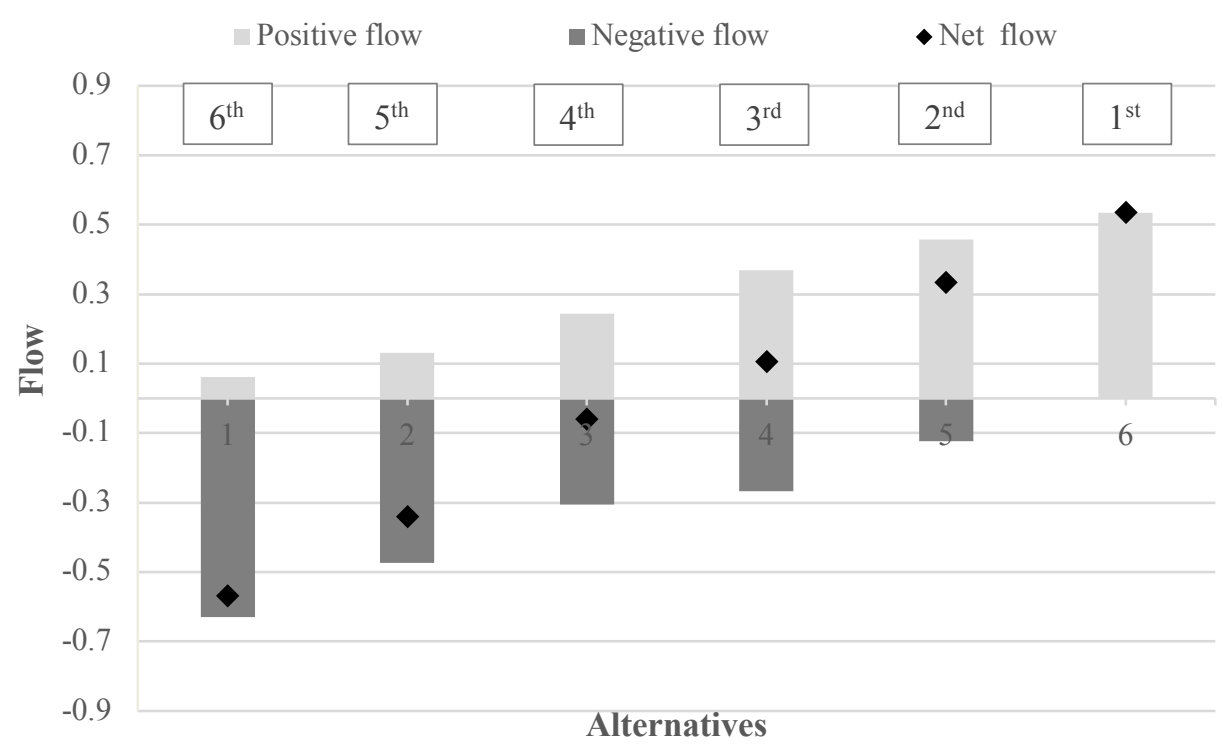

Figure 3. Positive, negative and net flow of each alternative and consequent sustainability ranking. (Key: Alternative 1: HMA, 0\%RAP; Alternative 2: WMA- CECABASE ${ }^{\circledR}$, 0\%RAP; Alternative 3: Foamed WMA, 0\%RAP; Alternative 4: HMA, 50\%RAP; Alternative 5: WMA- CECABASE ${ }^{\circledR}, 50 \% R A P$; Alternative 6: Foamed WMA, 50\%RAP).

\subsection{Sensitivity analysis}

To investigate how variations across a set of parameters and assumptions affect the robustness of the reported ranking, and thereby the relative merits of the alternatives being considered and compared, a sensitivity analysis was performed. In particular, the "One(factor)-At-a-Time" (OAT) sensitivity analysis method was used (Pianosi et al., 2016). In this method, output variations are induced by varying one input factor at a time, while all others are held at their default values.

The sensitivity analysis was focused on the determination of the influence of the weight values and PROMETHEE thresholds.

\subsubsection{Indicators weighting}

The sensitivity of the ranking to changes in the indicators weights was carried out by considering two additional weighting approaches: (1) the mean weighting method, and (2) the Entropy method. 
Figure 4 shows the weights values derived from the two alternative weighting methods as well as the relative variation in relation to the weights set of the base case scenario. Table 5 displays the ranking of alternatives for each sensitivity analysis scenario. As observed from Figure 4, although the relative importance of the indicators changes considerably, the ranking of the alternatives proved to be robust, as no changes in the rankings were observed regardless of the weighting method considered.

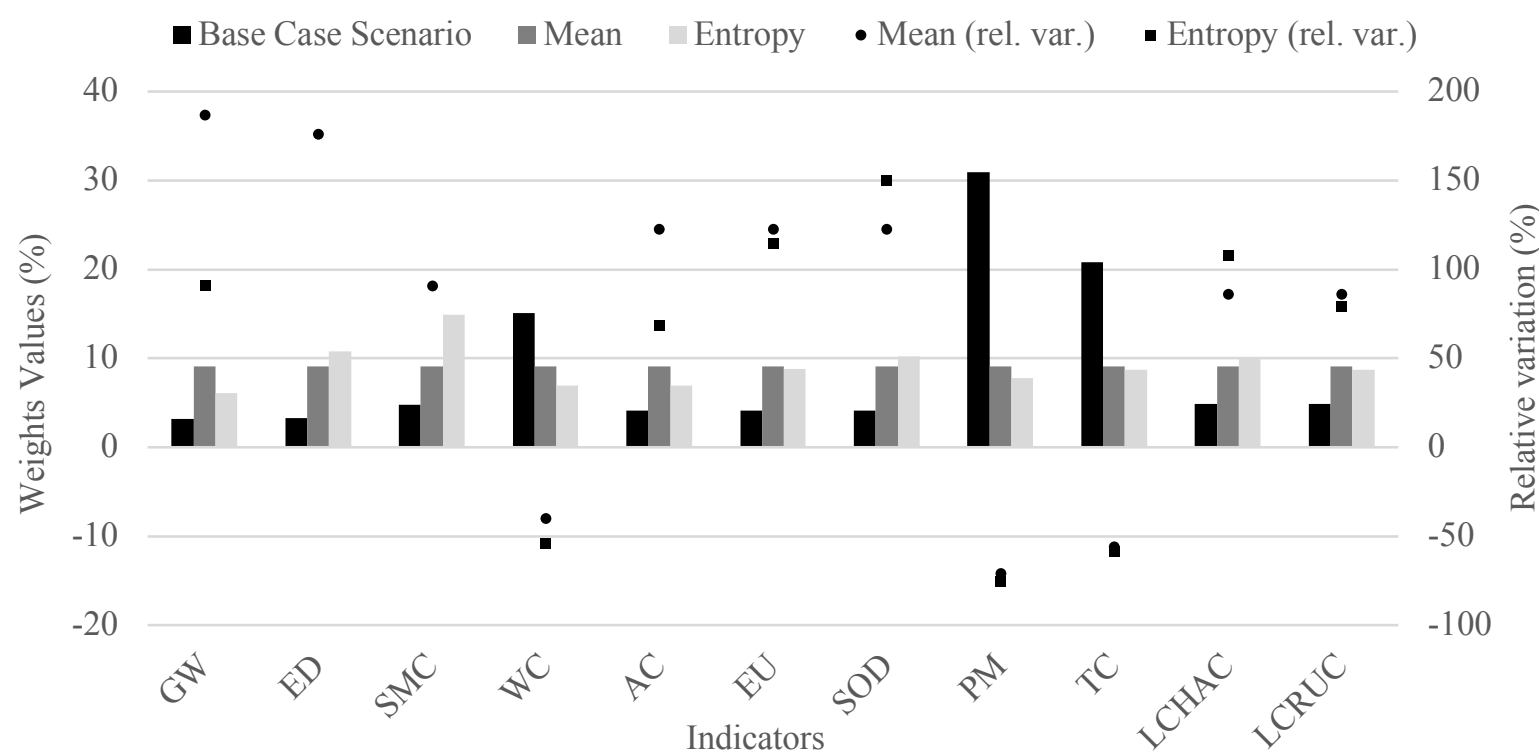

Figure 4. Indicator weights for each alternative weighting method and relative variation in relation to the weights set of the base case scenario. (Key: GW-global warming; EDEnergy demand; SMC- Secondary materials consumption; WC- Water consumption; AC- acidification; EU- Eutrophication; SOD- Stratospheric ozone depletion; PMParticulate matter; TC- Traffic congestion; LCHAC- Life cycle highway agency costs; LCRUC- Life cycle road user costs; rel. var.- relative variation).

7 Table 5. Ranking of alternatives for each sensitivity analysis scenario.

\begin{tabular}{|c|c|c|c|c|c|c|c|c|c|c|c|c|}
\hline \multirow{3}{*}{$\begin{array}{l}\text { Alternative } \\
\text { name }\end{array}$} & \multicolumn{12}{|c|}{ Weighting method } \\
\hline & \multicolumn{4}{|c|}{ Base case scenario } & \multicolumn{4}{|l|}{ Mean } & \multicolumn{4}{|l|}{ Entropy } \\
\hline & $\phi^{+}$ & $\phi^{-}$ & $\phi$ & Rank. & $\phi^{+}$ & $\phi^{-}$ & $\phi$ & Rank. & $\phi^{+}$ & $\phi^{-}$ & $\phi$ & Rank. \\
\hline $\begin{array}{l}\text { Conventional } \\
\text { HMA }\end{array}$ & 0.0606 & 0.6217 & -0.5611 & 6 & 0.0367 & 0.6448 & -0.6081 & 6 & 0.0282 & 0.6454 & -0.6171 & 6 \\
\hline $\begin{array}{l}\text { WMA- } \\
\text { CECABASE } \\
, 0 \% \text { RAP } \\
\text { Foamed }\end{array}$ & 0.1152 & 0.4993 & -0.3840 & 5 & 0.0875 & 0.5255 & -0.4380 & 5 & 0.0811 & 0.5262 & -0.4451 & 5 \\
\hline $\begin{array}{l}\text { WMA, } \\
0 \% \text { RAP }\end{array}$ & 0.2299 & 0.3302 & -0.1004 & 4 & 0.1775 & 0.4071 & -0.2296 & 4 & 0.1584 & 0.4317 & -0.2733 & 4 \\
\hline $\begin{array}{l}\text { HMA, } \\
50 \% \text { RAP } \\
\text { WMA- }\end{array}$ & 0.3943 & 0.2345 & 0.1598 & 3 & 0.4431 & 0.1757 & 0.2675 & 3 & 0.4597 & 0.1625 & 0.2973 & 3 \\
\hline $\begin{array}{l}\text { CECABASE }^{\circledR} \\
, 50 \% \text { RAP } \\
\text { Foamed }\end{array}$ & 0.4661 & 0.1231 & 0.3431 & 2 & 0.5180 & 0.0746 & 0.4434 & 2 & 0.5298 & 0.0579 & 0.4719 & 2 \\
\hline $\begin{array}{l}\text { WMA, } \\
50 \% \text { RAP }\end{array}$ & 0.5426 & 0.0000 & 0.5426 & 1 & 0.5649 & 0.0000 & 0.5649 & 1 & 0.5664 & 0.0000 & 0.5664 & 1 \\
\hline
\end{tabular}

18 Key: HMA- hot mix asphalt; WMA- warm mix asphalt; RAP- recycled asphalt pavement; Rank. - ranking; $\phi^{+}$- positive flow; $\phi^{-}$- negative

\subsubsection{PROMETHEE preference function parameters}

The sensitivity of the ranking to changes in the threshold parameters was carried out by considering two alternative values for each threshold parameter (i.e., indifference and 
preference thresholds). The values of the threshold parameters considered in the sensitivity analysis are reported in Table 6. Table 7 displays the ranking of alternatives for various threshold values. Likewise, the ranking of the alternatives was found to be robust, as no changes in the rankings were observed, regardless of the threshold values considered.

Table 6. Threshold parameters considered for each sensitivity analysis scenario

\begin{tabular}{|c|c|c|c|c|c|c|c|c|}
\hline \multirow{2}{*}{$\begin{array}{l}\text { Sustainability } \\
\text { indicator }\end{array}$} & \multicolumn{4}{|c|}{ Base case scenario } & \multirow{2}{*}{$\begin{array}{l}\begin{array}{l}\text { Alt. } \\
\text { scenario 1 }\end{array} \\
d_{j}^{p}(\%)\end{array}$} & \multirow{2}{*}{$\begin{array}{l}\begin{array}{l}\text { Alt. } \\
\text { scenario } 2\end{array} \\
d_{j}^{p}(\%)\end{array}$} & \multirow{2}{*}{$\begin{array}{l}\text { Alt. } \\
\text { scenario } 3 \\
d_{j}^{q}(\%)\end{array}$} & \multirow{2}{*}{$\begin{array}{l}\begin{array}{l}\text { Alt. } \\
\text { scenario } 4\end{array} \\
d_{j}^{q}(\%)\end{array}$} \\
\hline & $d_{j}^{p}(\%)$ & Abs. value & $d_{j}^{q}(\%)$ & Abs. value & & & & \\
\hline $\mathrm{GW}$ & 65 & 51688.65 & 5 & 3976.05 & 50 & 80 & 10 & 15 \\
\hline ED & 65 & 4093831.30 & 5 & 314910.10 & 50 & 80 & 10 & 15 \\
\hline SMC & 65 & 7.15 & 5 & 0.55 & 50 & 80 & 10 & 15 \\
\hline WC & 65 & 1229.15 & 5 & 94.55 & 50 & 80 & 10 & 15 \\
\hline $\mathrm{AC}$ & 65 & 484.90 & 5 & 37.30 & 50 & 80 & 10 & 15 \\
\hline EU & 65 & 172.25 & 5 & 13.25 & 50 & 80 & 10 & 15 \\
\hline SOD & 65 & 0.04875 & 5 & 0.00375 & 50 & 80 & 10 & 15 \\
\hline PM & 65 & 124.80 & 5 & 9.60 & 50 & 80 & 10 & 15 \\
\hline $\mathrm{TC}$ & 65 & 3.39 & 5 & 0.26 & 50 & 80 & 10 & 15 \\
\hline LCHAC & 65 & 43596.15 & 5 & 3353.55 & 50 & 80 & 10 & 15 \\
\hline LCRUC & 65 & 66.95 & 5 & 5.15 & 50 & 80 & 10 & 15 \\
\hline
\end{tabular}

7 Key: GW- global warming; ED- Energy demand; SMC- Secondary materials consumption; WC- Water consumption; AC8 acidification; EU- Eutrophication; SOD- Stratospheric ozone depletion; PM- Particulate matter; TC- Traffic congestion;

9 LCHAC- Life cycle highway agency costs; LCRUC- Life cycle road user costs; $d_{j}^{p}$ - preference threshold for the indicator $j$,

10 expressed as the difference (\%) between the highest and lowest score of that indicator; $d_{j}^{q}$ - indifference threshold for the 11 indicator $j$, expressed as the difference (\%) between the highest and lowest score of that indicator.

12

13 Table 7. Ranking of alternatives for each sensitivity analysis scenario.

\begin{tabular}{|c|c|c|c|c|c|c|c|c|c|c|}
\hline \multirow{2}{*}{$\begin{array}{l}\text { Alternative } \\
\text { name }\end{array}$} & \multicolumn{2}{|c|}{ Base case scenario } & \multicolumn{2}{|l|}{$d_{j}^{p}=50 \%$} & \multicolumn{2}{|c|}{$d_{j}^{p}=80 \%$} & \multicolumn{2}{|c|}{$d_{j}^{q}=10 \%$} & \multicolumn{2}{|c|}{$d_{j}^{q}=15 \%$} \\
\hline & $\phi$ & Rank. & $\phi$ & Rank. & $\phi$ & Rank. & $\phi$ & Rank. & $\phi$ & Rank. \\
\hline $\begin{array}{l}\text { Conventional } \\
\text { HMA }\end{array}$ & -0.5611 & 6 & -0.5814 & 6 & -0.5480 & 6 & -0.5439 & 6 & -0.5336 & 6 \\
\hline $\begin{array}{l}\text { WMA- } \\
\text { CECABASE }^{\circledR} \text {, } \\
0 \% \text { RAP }\end{array}$ & -0.3840 & 5 & -0.3908 & 5 & -0.3687 & 5 & -0.3797 & 5 & -0.3753 & 5 \\
\hline $\begin{array}{l}\text { Foamed WMA, } \\
0 \% \text { RAP }\end{array}$ & -0.1004 & 4 & -0.1041 & 4 & -0.0701 & 4 & -0.1076 & 4 & -0.1187 & 4 \\
\hline HMA, $50 \%$ RAP & 0.1598 & 3 & 0.1726 & 3 & 0.1409 & 3 & 0.1647 & 3 & 0.1710 & 3 \\
\hline $\begin{array}{l}\text { WMA- } \\
\text { CECABASE }^{\circledR} \text {, } \\
50 \% \text { RAP }\end{array}$ & 0.3431 & 2 & 0.3519 & 2 & 0.3230 & 2 & 0.3363 & 2 & 0.3329 & 2 \\
\hline $\begin{array}{l}\text { Foamed WMA, } \\
50 \% \text { RAP }\end{array}$ & 0.5426 & 1 & 0.5517 & 1 & 0.5229 & 1 & 0.5302 & 1 & 0.5237 & 1 \\
\hline
\end{tabular}
expressed as the difference $(\%)$ between the highest and lowest score of that indicator; $d_{j}^{q}$ - indifference threshold for the indicator $j$, expressed as the difference (\%) between the highest and lowest score of that indicator; $\phi$ net flow; Rank.- ranking.

\section{Summary and conclusions}

In this paper, a Decision Support System is developed with the ultimate objective of 18 fostering sustainable development in pavement engineering. The proposed DSS embeds 20 several indicators methodologically selected for assessing the sustainability of road pavement 21 technologies according to the economic, environmental and social dimensions of sustainability. 22 PROMETHEE-II MCDM method is employed to rank the priority sequence of the alternatives 23 being compared, with the consideration of the DMs' preferences or based on the relationship between the performances of the alternatives with respect to each indicator. 
The capabilities of the proposed sustainability-based DSS were illustrated through a comparative analysis of several sustainable asphalt mixtures used in wearing courses of a flexible road pavement. Specifically, six type of mixtures, namely (1) a conventional HMA mixture with $0 \% \mathrm{RAP},(2)$ a foamed WMA mixture with $0 \% \mathrm{RAP},(3)$ a WMA-CECABASE ${ }^{\circledR}$ additive mixture with $0 \% \mathrm{RAP}$, (4) a conventional HMA mixture with 50\%RAP, (5) a WMA$\mathrm{CECABASE}^{\circledR}$ additive mixture with 50\%RAP, and (6) a foamed WMA mixture with 50\%RAP were ranked with regard to eleven sustainability indicators. They were the following: (1) global warming; (2) energy demand; (3) secondary materials consumption; (4) water consumption; (5) acidification of soil and water; (6) eutrophication; (7) ozone depletion; (8) particulate matter; (9) traffic congestion; (10) life cycle highway agency costs; and (11) life cycle road user costs.

From the methodology and results presented and discussed in the previous sections, the following results are worth highlighting:

- All in all, by providing a computational platform embedding a representative and clear set of indicators and by allowing an easily interpretation of the results, the proposed sustainability-based DSS proved to be efficient in identifying the most sustainable alternatives.

- As a results of the MCDA, the results from the baseline case scenario show that the mixture foamed WMA with $50 \%$ RAP is the most sustainable among the competing alternatives, followed by the mixture WMA-CECABASE ${ }^{\circledR}$ additive with 50\%RAP and the mixture HMA with 50\%RAP. In turn, the conventional HMA mixture was found to be the least sustainable.

- A sensitivity analysis conducted to investigate the influence of modified weight and threshold values on the stability of the ranking showed that it remained unchanged regardless of the analysis scenario considered.

- The presented sustainability-based DSS has been structured in a way that allows DMs to apply it to several systems. It is an ambition of the authors that this methodology and tool could be adapted and used by DM to compare the sustainability of a technology already at the design stage.

Although the authors believe that the DSS presented in this paper, and soon freely available on http://superitn.eu, can already be seen as a useful tool for helping DMs striving for more sustainable transportation infrastructure, it can still benefit from further improvements. Therefore, further work concerning its development will follow two main directions. First, the number of MCDA methods available for selection will be extended. Second, the methodological context in which the MCDA is currently performed (i.e. deterministic) will be enhanced to allow a stochastic MCDA to be performed.

\section{Acknowledgements and disclaimer}

The research presented in this paper was carried out as part of the Marie Curie Initial Training Network (ITN) action, FP7-PEOPLE-2013-ITN. This project has received funding from the European Union's Seventh Framework Programme for research, technological development and demonstration under grant agreement number 607524.

The contents of this paper reflect the views of the authors, who are responsible for the facts and the accuracy of the data presented. Any inclusion of manufacturer names, trade names, or trademarks is for identification purposes only and is not to be considered an endorsement. Moreover, this paper does not constitute a standard, specification, or regulation.

\section{References}


An, D., Xi, B., Ren, J., Wang, Y., Jia, X., He, C., Li, Z., 2017. Sustainability assessment of groundwater remediation technologies based on multi-criteria decision making method. Resour. Conserv. Recycl. 119, 36-46. http://dx.doi.org/10.1016/j.resconrec.2016.08.002.

Arce, M.E., Saavedra, A., Míguez, J.L., Granada, E., 2015. The use of grey-based methods in multi-criteria decision analysis for the evaluation of sustainable energy systems: a review. $\begin{array}{lllll}\text { Renewable Sustainable } & \text { Energy } & \text { Rev. } & \text { 47, }\end{array}$ http://dx.doi.org/10.1016/j.rser.2015.03.010.

Behzadian, M., Kazemzadeh, R., Albadvi, A., Aghdasi, M., 2010. PROMETHEE: a comprehensive literature review on methodologies and applications. Eur. J. Oper. Res. 200, 198-215. http://dx.doi.org/10.1016/j.ejor.2009.01.021.

Betrie, G., Sadiq, R., Morin, K.A., Tesfamariam, S., 2013. Selection of remedial alternatives for mine sites: A multicriteria decision analysis approach. J. Environ. Manag. 119, 36-46. http://dx.doi.org/10.1016/j.jenvman.2013.01.024.

Brans, J., Mareschal, B., 2005. PROMETHEE methods, in: Figueira, J., Greco, S., Ehrgott, M. (Eds.), Multiple criteria analysis - state of the art surveys. International series in operations research and management sciences. Springer, New York, USA, pp. 163-195.

Brans, J.P., Vincke, P., 1985. A preference ranking organisation method: (the PROMETHEE method for multiple criteria decision-making). Manage. Sci. 31, 647-656. http://dx.doi.org/10.1287/mnsc.31.6.647.

Birgisdóttir, H., Pihl, K., Bhander, G., Hauschild, M., Christensen, T., 2006. Environmental assessment of roads constructed with and without bottom ash from municipal solid waste incineration. Transp. Res. Part D: Transp. Environ. 11, 358-368. http://dx.doi.org/10.1016/j.trd.2006.07.001.

Bryce, J. Brodie, S., Parry, T., Lo Presti, D., 2017. A systematic assessment of road pavement sustainability through a review of rating tools. Resour. Conserv. Recycl. 120, 108-118. https://doi.org/10.1016/j.resconrec.2016.11.002.

Cai, Y., Applegate, S., Yue, W., Cai, Y., Wang, X., Liu, G., Li, C., 2017. A hybrid life cycle and multi-criteria decision analysis approach for identifying sustainable development strategies of Beijing's taxi fleet. Energy Policy 100, 314-325. http://dx.doi.org/10.1016/j.enpol.2016.09.047.

Carbone, A., Caswell, J., Galli, F., Sorrentino, A., 2014. The Performance of protected designations of origin: an ex post multi-criteria assessment of the Italian cheese and olive oil sectors. J. Agric. Food Ind. Organ. 12, 121-140. https://doi.org/10.1515/jafio-2013$\underline{0017}$.

Carpenter, A., Gardner, K., 2009. Use of industrial by-products in urban roadway infrastructure. Argument for increased industrial ecology. J. Ind. Ecol. 13, 965-977. http://dx.doi.org/10.1111/j.1530-9290.2009.00175.x.

Carpenter, A., Gardner, K., Fopiano, J., Benson, C., Edil, T., 2007. Life cycle based risk assessment of recycled materials in roadway construction. Waste Manag. 27, 1458-1464. http://dx.doi.org/10.1016/j.wasman.2007.03.007.

Cinelli, M., Coles, S.R., Kirwan, K., 2014. Analysis of the potentials of multi criteria decision analysis methods to conduct sustainability assessment. Ecol. Indic. 46, 138-148. http://dx.doi.org/10.1016/j.ecolind.2014.06.011.

Directive 2008/96/EC of the European Parliament and of the Council of 19 November 2008 on road infrastructure safety management. Off. J. Eur. Union 319, 59-67. http://data.europa.eu/eli/dir/2008/96/oj.

Dražić, J., Dunjić, D., Mučenski, V., 2016. Multi-criteria analysis of variation solutions for the pipeline route by applying the PROMETHEE method. Tech. Gaz. 23, 599-610. https://doi.org/10.17559/TV-20150305124627. 
Ekins, P., Simon, S., Deutsch, L., Folke, C., De Groot, R., 2003. A framework for the practical application of the concepts of critical natural capital and strong sustainability. Ecol. Econ. 44, 165-185. https://doi.org/10.1016/S0921-8009(02)00272-0.

European Union Road Federation (ERF), 2013. ERF 2012 European Road Statistics. European Union Road Federation, Brussels, Belgium.

Frischknecht, R., Wyss, F., Knöpfel, S. B., Lützkendorf, T., Balouktsi, M., 2015. Cumulative energy demand in LCA: the energy harvested approach. Int. J. Life Assess. 20, 957-969. http://dx.doi.org/10.1007/s11367-015-0897-4.

Geldermann, J. and Rentz, O. 2005. Multi-criteria analysis for technique assessment: case study from industrial coating. $J$ Ind. Ecol. 9, 127-142. http://dx.doi.org/10.1162/1088198054821591.

Gervásio, H., Simões da Silva, L., 2012. A probabilistic decision-making approach for the sustainable assessment of infrastructures. Expert Syst. with Appl. 39, 7121-7131. http://dx.doi.org/10.1016/j.eswa.2012.01.032.

Giustozzi, F., Crispino, M., Flintsch, G., 2012. Multi-attribute life cycle assessment of preventive maintenance treatments on road pavements for achieving environmental sustainability. Int. J. Life Assess. 17, 409-419, http://dx.doi.org/10.1007/s11367-011-03756.

Goedkoop, M.J., Heijungs, R., Huijbregts, M., De Schryver, A., Struijs, J., Van Zelm, R., 2013. ReCiPe 2008. A life cycle impact assessment method which comprises harmonised category indicators at the midpoint and the endpoint level. First edition, Report I: Characterisation.

Greco, S., Matarazzo, B., Słowinski, R., 2004. Axiomatic characterization of a general utility function and its particular cases in terms of conjoint measurement and rough-set decision rules. Eur. J. Oper. Res. 158, 271-292.

Guinée, J. B., Gorrée, M., Heijungs, R., Huppes, G., Kleijn, R., de Koning, A., van Oers, L., Sleeswijk, A. W., Suh, S., Udo de Haes, H. A., de Bruijn, H., van Duin, R., Huijbregts, M. A. J.. 2002. Handbook on Life Cycle Assessment. Operational Guide to the ISO Standards. I: LCA in Perspective. IIa: Guide. IIb: Operational Annex. III: Scientific Background, Kluwer Academic Publishers, Dordrecht, The Netherlands.

Haider, H., Sadiq, R., Tesfamariam, S., 2016. Intra-utility performance management model (In-UPM) for the sustainability of small to medium sized water utilities: conceptualization to development. J. Cleaner Prod. 1333, 777-794. https://doi.org/10.1016/j.jclepro.2016.06.003.

Hischier, R., Weidema, B., Althaus, H.-J., Bauer, C., Doka, G., Dones, R., Frischknecht, R., Hellweg, S., Humbert, S., Jungbluth, N., Köllner, T., Loerincik, Y., Margni, M., Nemecek T., 2010. Implementation of life cycle impact assessment methods. ecoinvent report No. 3, v2.2. Swiss Centre for Life Cycle Inventories, Dübendorf.

Huang, Y., Bird, R., Heidrich, O., 2009. Development of life cycle assessment tool for construction and maintenance of asphalt pavements. J. Clean. Prod. 17, 283-296. http://dx.doi.org/10.1016/j.jclepro.2008.06.005.

Huang, I.B., Keisler, J., Linkov, I., 2011. Multi-criteria decision analysis in environmental sciences: Ten years of applications and trends. Sci. Total Environ. 409, 3578-3594. http://dx.doi.org/10.1016/j.scitotenv.2011.06.022.

ITF (International Transport Forum) 2017. ITF transport outlook 2017, OECD Publishing, Paris. http://dx.doi.org/10.1787/9789282108000-en

Illinois Interchange, 2012. Recycling/reclaiming a savings spree. Illinois Technology Transfer Center, Illinois Department of Transportation, vol. 2012-02.

Institute for Sustainable Infrastructure, 2012. Envision V 2.0- a rating system for sustainable infrastructure. Institute for Sustainable Infrastructure. 
Jullien, A., Dauvergne, M., Cerezo, V., 2014. Environmental assessment of road construction and maintenance policies using LCA. Transp. Res. Part Transp. Environ. 29, 56-65. http://dx.doi.org/10.1016/j.trd.2014.03.006.

Jullien, A., Cerezo, V., Keijzer, E., Lòpez, A.-M., 2015. ECOLABEL. Deliverable D1.4: benchmarking exercise to assess the set of proposed indicators in diverse road case studies. 1-106.

Keeney, R.L., Raiffa, H., 1993. Decisions with multiple objectives: preferences and value trade-offs. Cambridge University Press, London, England.

Khishtandar, S., Zandieh, M., Dorri, B., 2016. A multi criteria decision making framework for sustainability assessment of bioenergy production technologies with hesitant fuzzy linguistic term sets: the case of Iran. Renewable Sustainable Energy Rev. http://dx.doi.org/10.1016/j.rser.2016.11.212.

Kiker, G.A., Bridges, T.S., Varghese, A., Seager, T.P., Linkov, I., 2005. Application of multicriteria decision analysis in environmental decision-making. Integr. Environ. Assess. Manag. 1, 1-14. http://dx.doi.org/10.1897/IEAM_2004a-015.1.

Kilic, H. S., Zaim, S., Delen, D., 2015. Selecting “The Best”' ERP system for SMEs using a combination of ANP and PROMETHEE methods. Expert Syst. With Appl. 42, 2343-2352. http://dx.doi.org/10.1016/j.eswa.2014.10.034.

Kucukvar, M., Gumus, S., Egilmez, G., and Tatari, O., (2014). Ranking the sustainability performance of pavements: An intuitionistic fuzzy decision making method. Autom. Constr. 40, 33-43. http://dx.doi.org/10.1016/j.autcon.2013.12.009 Lane, B., Lee, S., Bennett, B., Chan, S., 2014. GreenPave Reference Guide: Version 2.0. Ministry of Transportation's Materials Engineering and Research Office, Toronto: Ontario.

Laurent, G., 2004. Evaluation économique des chaussées en béton et classiques sur le réseau routier national français. Ed. LCPC, Paris, 83 pages.

Lee, J.C., Edil, T.B., Benson, C.H., Tinjum, J.M., 2011. Evaluation of variables affecting sustainable highway design with $\mathrm{BE}^{2} \mathrm{ST}$-in-highways. Transp. Res. Rec. J. Transp. Res. Board, 2233, 178-186. https://doi.org/10.3141/2233-21.

Lee, J., Edil, T. B., Tinjum, J., Benson, C., 2010. Quantitative assessment of environmental and economic benefits of recycled materials in highway construction. Transp. Res. Rec. J. Transp. Res. Board 2158, 138-142. http://dx.doi.org/10.3141/2158-17.

Linkov, I., Varghese, A., Jamil, S., Seager, T.P., Kiker, G., Bridges, T., 2004. Multi-criteria decision analysis: a framework for structuring remedial decisions at contaminated sites, in: Linkov, I. and Ramadan, A. (Eds), Comparative Risk Assessment and Environmental Decision Making, Kluwer, Amsterdam, The Netherlands, pp. 15-54.

Liou, J.J.H., Tzeng, G.-H., 2012. Comments on "Multiple criteria decision making (MCDM) methods in economics: an overview". Technol. Econ. Dev. Econ. 18, 672-695. http://dx.doi.org/10.3846/20294913.2012.753489.

Lo Presti, D., Airey, G., Rubio, M., Marsac, P., 2017. SUP\&R ITN: an international training network on sustainable pavements and railways, in: Dell'Acqua, G. and Wegman, F. (Eds), Transport Infrastructure and Systems: Proceedings of the Aiit International Congress on Transport Infrastructure and Systems (TIS 2017), Rome, Italy, 10-12 April 2017, CRC Press/Balkema P.O. Box 11320, 2301 EH Leiden, The Netherlands CRC Press/Balkema 2017, pp. 47-54, Print ISBN: 978-1-138-03009-1. https://doi.org/10.1201/9781315281896$\underline{9}$.

Lo Presti, D., Carrión, A., Airey, G., Hajj, E., 2016. Towards 100\% recycling of reclaimed asphalt in road surface courses: binder design methodology and case studies. J. Cleaner Prod. 131, 43-51. https://doi.org/10.1016/j.jclepro.2016.05.093. 
Ministère de la Transition Écologique et Solidaire, 2017. Observation et statistiques. $\underline{\mathrm{http}}$ //developpementdurable.bsocom.fr/Statistiques/TableViewer/tableView.aspx?ReportId=15233

Mitropoulos, L.K., Prevedouros, P.D., 2014. Multicriterion sustainability assessment in transportation: private cars, carsharing, and transit buses. Transp. Res. Rec. J. Transp. Res. Board. 2403, 52-61. http://dx.doi.org/10.3141/2403-07.

Mladenovič, A., Turk, J., Kovač, J., Mauko, A., Cotič, Z., 2015. Environmental evaluation of two scenarios for the selection of materials for asphalt wearing courses. J. Clean. Prod. 87, 683-691. http://dx.doi.org/10.1016/j.jclepro.2014.10.013.

Muench, S. T., Anderson, J., Bevan, T., 2010. Greenroads: a sustainability rating system for roadways. Int. J. Pavement Res. Technol. 3, 270-279.

Munda, G., 2005. Multiple criteria decision analysis and sustainable development, in: Figueira, J., Greco, S., Ehrgott, M. (Eds.), Multiple criteria analysis - state of the art surveys. International series in operations research and management sciences. Springer, New York, USA, pp. 954-986.

NYSDOT (New York State Department of Transportation), 2010. GreenLITES-Recognizing Leadership in Transportation Environmental Sustainability. GreenLITES for Sustainable Planning. New York State Department of Transportation.

Ozer, H., Yang, R., Al-Qadi, I.L., 2017. Quantifying sustainable strategies for the construction of highway pavements in Illinois. Transp. Res. Part Transp. Environ. 51, 1-13. http://dx.doi.org/10.1016/j.trd.2016.12.005.

Pianose, F., Beven, K., Freer, J., Hall, J. W., Rougier, J., Stephenson, D. B., Wagener, T., 2016. Sensitivity analysis of environmental models: a systematic review with practical workflow. Environ. Model. Softw. 79, 214-232. http://dx.doi.org/10.1016/j.envsoft.2016.02.008.

Pires, G., Carrión, A., Airey, G., Lo Presti, D., 2017. Maximising asphalt recycling in road surface courses: The importance of a preliminary binder design, in: Loizos, A., Al-Qadi, I., Scarpas, T. (Eds.), Bearing Capacity of Roads, Railways and Airfields: Proceedings of the 10th International Conference on the Bearing Capacity of Roads, Railways and Airfields (BCRRA 2017), Athens, Greece, June 28-30, 2017, CRC Press/Balkema, Taylor \& Francis Group, London, pp. 1225-1233, Print ISBN 978-1-138-29595-7.

Podvezko, V., Podviezko, A., 2010. Dependence of multi-criteria evaluation result on choice of preference functions and their parameters. Technol. Econ. Dev. Econ. 16, 143-158. http://dx.doi.org/10.3846/tede.2010.09.

Pohekar, S.D., Ramachandran, M., 2004. Application of multi-criteria decision making to sustainable energy planning-a review. Renew. Sustain. Energy Rev. 8 (4), 365-381. http://dx.doi.org/10.1016/j.rser.2003.12.007.

Reza, B., Sadiq, R., Hewage, K.N., 2011. Sustainability assessment of flooring systems in the city of Tehran: An AHP-based life cycle analysis. Constr. Build. Mater. 25, 2053-2066. http://dx.doi.org/10.1016/j.conbuildmat.2010.11.041.

Robinette, C., Epps, J., 2010. Energy, emissions, material conservation, and prices associated with construction, rehabilitation, and material alternatives for flexible pavement. Transp. Res. Rec. J. Transp. Res. Board, 2179, 10-22, http://dx.doi.org/10.3141/2179-02.

Rogers, M., Bruen, M., 1998. Choosing realistic values of indifference, preference and veto thresholds for use with environmental criteria within ELECTRE. Eur. J. Oper. Res. 107, 542-551. http://dx.doi.org/10.1016/S0377-2217(97)00175-6.

Roy, B., 1991. The outranking approach and the foundations of ELECTRE methods. Theory Decis. 31, 49-73. http://dx.doi.org/10.1007/BF00134132.

Rubio, M., Martínez, G., Baena, L., Moreno, F., 2012. Warm mix asphalt: an overview. J. Clean. Prod. 24, 76-84. http://dx.doi.org/10.1016/j.jclepro.2011.11.053. 
Saaty, T.L., 1988. Mathematical models for decision support. What is the analytic hierarchy process? Springer, Berlin, Germany.

Sakhaeifar, M., Brown, E., Tran, N., Dean, J., 2013. Evaluation of long-lasting perpetual asphalt pavement with life-cycle cost analysis. Transp. Res. Rec. J. Transp. Res. Board 2368, 3-11. http://dx.doi.org/10.3141/2368-01.

Santero, N., Horvath, A., 2009. Global warming potential of pavements. Environ. Res. Lett. 4, 1-7. http://iopscience.iop.org/article/10.1088/1748-9326/4/3/034011.

Santos, J., Flintsch, G., Ferreira, A., 2017a. Environmental and economic assessment of pavement construction and management practices for enhancing pavement sustainability. Resour. Conserv. Recycl. 116, 15-31. http://dx.doi.org/10.1016/j.resconrec.2016.08.025.

Santos, J., Bryce, J.M., Flintsch, G., Ferreira, A., 2017b. A comprehensive life cycle costs analysis of in-place recycling and conventional pavement construction and maintenance $\begin{array}{llllll}\text { practices. Int. J. Pavement } & \text { Eng. }\end{array}$ http://dx.doi.org/10.1080/10298436.2015.1122190

Santos, J., Bressi, S., Cerezo, V., Dauvergne, M., Lo Presti, D., 2017c. A comparative life cycle assessment of conventional and low-temperature asphalt mixtures containing reclaimed asphalt pavement. J. Clean. Prod. (submitted for publication).

Santos, J., Bryce, J., Flintsch, G., Ferreira, A., Diefenderfer, B., 2015a. A life cycle assessment of in-place recycling and conventional pavement construction and maintenance practices. Struct. Infrastruct. Eng.: Maint. Manag. Life-Cycle Des. Perform. 11, 119-1217. http://dx.doi.org/10.1080/15732479.2014.945095.

Sayagh, S., Ventura, A., Hoang, T., Francois, D., Jullien, A., 2010. Sensitivity of the LCA allocation procedure for BFS recycled into pavement structures. Resour. Conserv. Recycl. 54, 348-358. http://dx.doi.org/10.1016/j.resconrec.2009.08.011.

Schmitt, E., Galli, F., Menozzi, D., Maye, D., Touzard, J.-M., Marescotti, A., Six, J., Brunori, G., 2017. Comparing the sustainability of local and global food products in Europe. J Clean. Prod. (Available online). https://doi.org/10.1016/j.jclepro.2017.07.039.

Simpson, S.P., Mehmet, E.O., Clevenger, M.C., Rebecca, A.A., 2014. A framework for assessing transportation sustainability rating systems for implementation in U.S. State Departments of Transportation, MPC-14-268. North Dakota State University - Upper Great Plains Transportation Institute, Fargo: Mountain-Plains Consortium.

Slowinski, R., Greco, S., Matarazzo, B., 2002. Axiomatization utility decision-rule of utility, outranking and decision preference models for multiple-criteria classification problems under partial inconsistent with the dominance principle. Control Cybern. 31, 1005-1035.

Slowinski, R., Greco, S., Matarazzo, B., 2009. Rough sets in decision making, in: Meyers, R., Meyers, R. (Eds.), Encyclopedia of Complexity and Systems Science. Springer, New York, pp. 7753-7786.

Soltani, A., Hewage, K., Reza, B., Sadiq, R., 2015. Multiple stakeholders in multi-criteria decision-making in the context of Municipal Solid Waste Management: a review. Waste Manage. Res. 35, 318-328. http://dx.doi.org/10.1016/j.wasman.2014.09.010.

Sultana, A., Kumar, A., 2012. Ranking of biomass pellets by integration of economic, environmental and technical factors. Biomass Bioenergy 39, 344-355. http://dx.doi.org/10.1016/j.biombioe.2012.01.027.

Thenoux, G., González, A., Dowling, R., 2007. Energy consumption comparison for different asphalt pavements rehabilitation techniques used in Chile. Resour. Conserv. Recycl. 49, 325-339. http://dx.doi.org/10.1016/j.resconrec.2006.02.005.

Transportation Research Board (TRB), 2000. Highway capacity manual 2000. Washington, DC, TRB.

Umer, A., Hewage, K., Haider, H., Sadiq, R., 2017. Sustainability evaluation framework for pavement technologies: an integrated life cycle economic and environmental trade-off 
analysis. Transp. Res. Part Transp. Environ. 53, 88-101. http://dx.doi.org/10.1016/j.trd.2017.04.011.

Washington State University, Pennsylvania State University-Altoona, Louisiana Transportation Research Center, 2017. Long-term field performance of warm mix asphalt technologies. NCHRP Research Report 843, Transportation Research Board, Washington, D.C.

World Road Association, 2016. Appraisal of sustainability of transport infrastructures. Technical Commettee TC1.3 Climate Change and Sustainability. World Road Association (PIARC), France.

Zaumanis, M., Mallick, R., 2015. Review of very high-content reclaimed asphalt use in plantproduced pavements: state of the art. Int. J. Pavement Eng. 16, 39-55. http://dx.doi.org/10.1080/10298436.2014.893331.

Zavadskas, E.K., Turskis, Z., Kildiene, Z., 2014. State of art surveys of overviews on MCDM/MADM methods. Technol. Econ. Dev. Econ. 20, 165-179. http://dx.doi.org/10.3846/20294913.2014.892037 